\title{
Species assemblages of zooplanktonic crustaceans in mountain shallow ponds of Chile (Parque Cañi)
}

\author{
Patricio De los Ríos ${ }^{1,2} \&$ Guido Roa ${ }^{1}$ \\ ${ }^{1}$ Escuela de Ciencias Ambientales, Facultad de Recursos Naturales, Universidad Católica de Temuco. Casilla 15-D, Temuco, Chile. \\ ${ }^{2}$ Corresponding author. E-mail: prios@uct.cl
}

\begin{abstract}
Even though the Chilean lakes are characterized by their oligotrophy, a transition from oligotrophy to mesotrophy, due human intervention, has been reported in some lakes. Nevertheless, there are still some pristine and unpolluted small lakes and ponds in mountain zones, free of human intervention and surrounded by native forests. Nine unpolluted, oligotrophic and pristine water bodies located in Cañi Park, a mountain zone with altitudes between 1000 to $1500 \mathrm{~m}$ a.s.I and forests where Nothofagus dombeyi, N. pumilio and Araucaria araucana predominate, were studied. For each sampled lake, zooplankton was collected and environmental parameters were obtained (conductivity, total dissolved solids, and chlorophyll concentration). A null model of species co-occurrence was applied to determine randomness in species associations. All sites revealed low species richness $(<6)$; the calanoid copepod Boeckella gracilis Daday, 1902 was present in all sites. The results of the null model indicated randomness or absence of regulatory factors in species associations. Only few species occur in practically all localities. Also, a significant inverse association between chlorophyll concentration with percentage of calanoid copepods and a weak direct association between chlorophyll concentration and percentages of cladocerans were found.
\end{abstract}

KEY WORDS. Boeckella gracilis; null model; oligotrophy; zooplankton.

Lakes of southern Andes in Chile are characterized by their relatively great depth, large surface, oligotrophy, and glacial origin (Soto \& ZúñIga 1991, Steinhart et al. 1999, 2002). Due to the oligotrophy, their zooplankton assemblages are characterized by a low species richness (De Los Ríos \& Soto 2007a,b) and predominance of calanoid copepods (Sото \& ZúNIga 1991, De los Ríos \& Soto 2006). The species more often reported for these lakes are the calanoids Boeckella gracilipes (Daday, 1902), B. michaelseni (Mrázek, 1901), Tumeodiaptomus diabolicus (Brehm, 1936), Ceriodaphnia dubia (Richard, 1894), Daphnia pulex (De Geer, 1877) and Eubosmina hagmanni (Stingelin, 1903) (Soto \& ZúÑIga 1991, De Los Ríos \& Soto 2007b).

Similarly, the small lakes and shallow ponds located in the mountains of the north Patagonian Andes (DE Los Ríos et al. 2007) are also characterized by lack of pollution and ultraoligotrophy (STEINHART et al. 1999, 2002). Because they are so pristine and sheltered from human intervention, these lakes offer unique research opportunities under very natural (undisturbed) conditions, critical to the study of zooplankton assemblages and the role of chlorophyll concentration and conductivity as factors that regulate unpolluted water bodies (Sото \& De Los Ríos 2006). The present study determines the role of chlorophyll concentration and conductivity as factors on the regulation of zooplanktonic crustacean assemblages in costal environments of nine unpolluted and pristine lakes located in a mountain zone of southern Chile (Cañi Park, $38^{\circ} \mathrm{S}$, Chile).

\section{MATERIAL AND METHODS}

The present study was carried out at the Cañi Park, a privately protected, mountainous land. The local vegetation is characterized by the strong presence of Nothofagus dombeyi (Mirb.) Oerst. and N. pumilio (Poepp. and Endl), which in some areas coexist with $N$. obliqua (Mirb.) Oerst. In high altitude zones, Araucaria araucana (K. Koch) and N. pumilio predominate (Luebert \& Pliscoff 2006). In addition, the local vegetation also includes shrub and herb communities. The shrub communities are characterized by the presence of Chusquea quila (Kunth) Drymis andina (Reiche), Azora lanceolata (Hook), Desfontainia spinosa (Ruiz \& Pav), Berberis buxifolia (Lam.), B. darwinii (Hook), B. serratodentata (Lechl), and B. Montana (Gay), whereas herb communities include Mitraria coccinea (Cav), Adenocaulon chilense (Less), Viola reichei (Skotsb.), Osmorhiza chilensis (Hook), Nertera granadensis (Mutis ex Lf), Acaena ovalifolia (Ruiz et Pav.), and Uncina pheleoides (Cav.) (Hoffman, 2005; Luebert \& Pliscoff 2006). The park has numerous fishless, shallow ponds that can be accessed via mountain roads located ca $8 \mathrm{~km}$ from the main access to the park.

The study site, visited in January, 2008, included nine shallow ponds (Tab. I). January corresponds summer month with highest zooplankton abundances in the southern hemisphere (DE Los Ríos \& Soto 2006, 2007a, b). Water samples were taken to the laboratory where chlorophyll $a$ concentration, 
conductivity, and total dissolved solids were determined. Chlorophyll $a$ concentration was measured after acetone extraction (Wetzel \& Likens 1991) and total dissolved solids were measured using an YSI-30 sensor.
Qualitative samples were obtained by performing horizontal hauls in the pelagic and littoral zones using an Apstein net with $20 \mathrm{~cm}$ mouth diameter and $100 \mu \mathrm{m}$ mesh size, applying a methodology similar to that described for southern

Table I. Geographical location, chlorophyll "a" concentration, total dissolved solids, conductivity and crustacean species reported for the studied sites.

\begin{tabular}{|c|c|c|c|c|c|}
\hline Site & Geographical location & Chlorophyll a $(\mu \mathrm{g} / \mathrm{l})$ & TDS (mg/l) & Conductivity $(\mathrm{mS} / \mathrm{cm})$ & Species \\
\hline \multirow[t]{3}{*}{ Del Risco } & $39^{\circ} 15^{\prime} \mathrm{S}, 71^{\circ} 42^{\prime} \mathrm{W}$ & 0.7 & 0.01 & 8.000 & B. gracilis \\
\hline & & & & & C. dubia \\
\hline & & & & & M. longisetus \\
\hline \multirow[t]{5}{*}{ Negrita } & $39^{\circ} 15^{\prime} \mathrm{S}, 71^{\circ} 42^{\prime} \mathrm{W}$ & 2.7 & 0.01 & 0.300 & B. gracilis \\
\hline & & & & & M. longisetus \\
\hline & & & & & D. pulex \\
\hline & & & & & C. dubia \\
\hline & & & & & C. sphaericus \\
\hline \multirow[t]{4}{*}{ De los Patos } & $39^{\circ} 15^{\prime} \mathrm{S}, 71^{\circ} 42^{\prime} \mathrm{W}$ & 10.6 & 0.01 & 0.213 & B. gracilis \\
\hline & & & & & M. longisetus \\
\hline & & & & & D. pulex \\
\hline & & & & & D. chilense \\
\hline \multirow[t]{6}{*}{ Escondida } & $39^{\circ} 15^{\prime} \mathrm{S}, 71^{\circ} 42^{\prime} \mathrm{W}$ & 12.4 & 6.00 & 0.7 & B. gracilis \\
\hline & & & & & M. longisetus \\
\hline & & & & & D. pulex \\
\hline & & & & & C. dubia \\
\hline & & & & & D. chilense \\
\hline & & & & & Ch. sphaericus \\
\hline \multirow[t]{5}{*}{ Seca } & $39^{\circ} 15^{\prime} \mathrm{S}, 71^{\circ} 43^{\prime} \mathrm{W}$ & 12.3 & 0.01 & 0.537 & B. gracilis \\
\hline & & & & & M. longisetus \\
\hline & & & & & D. pulex \\
\hline & & & & & C. dubia \\
\hline & & & & & Ch. sphaericus \\
\hline \multirow[t]{3}{*}{ Negra } & $39^{\circ} 15^{\prime} \mathrm{S}, 71^{\circ} 42^{\prime} \mathrm{W}$ & 0.7 & 0.01 & 0.466 & B. gracilis \\
\hline & & & & & M. longisetus \\
\hline & & & & & H. araucana \\
\hline \multirow[t]{2}{*}{ Bella } & $39^{\circ} 15^{\prime} \mathrm{S}, 71^{\circ} 42^{\prime} \mathrm{W}$ & 0.7 & 0.01 & 0.212 & B. gracilis \\
\hline & & & & & D. chilense \\
\hline \multirow[t]{4}{*}{ Los Pastos } & $39^{\circ} 15^{\prime} \mathrm{S}, 71^{\circ} 43^{\prime} \mathrm{W}$ & 0.5 & 0.01 & 0.533 & B. gracilis \\
\hline & & & & & M. longisetus \\
\hline & & & & & C. dubia \\
\hline & & & & & D. chilense \\
\hline \multirow[t]{4}{*}{ Vaca Hundida } & $39^{\circ} 15^{\prime} \mathrm{S}, 71^{\circ} 42^{\prime} \mathrm{W}$ & 1.2 & 67.00 & 136.000 & B. gracilis \\
\hline & & & & & D. pulex \\
\hline & & & & & C. dubia \\
\hline & & & & & D. chilense \\
\hline
\end{tabular}


Patagonian shallow ponds (Soto \& De los Ríos 2006, De Los Ríos et al. 2008). Zooplankton samples were fixed with ethanol $\left(96^{\circ}\right)$ and identified using the descriptions of AraYA \& ZÚÑIGA (1985), Reid (1985), Bayly (1992), Pilati \& Menu-Marque (2002), and GonZÁlez (2003). The relative abundance of calanoids, cladocerans, and cyclopoids was determined according to the methodologies of De los Ríos \& Soto (2006) and Soto \& De los Ríos (2006).

The data were ordered using an absence/presence matrix. A Checkerboard score ("C-score"), a quantitative index of occurrence, measured the extent to which species co-occur less frequently than expected by chance alone (Gotelli 2000, 2001). Gotelli \& Entsminger (2004), Tiho \& Johens (2007) and Tondoh (2006) suggested that the following robust statistical models should be used in a co-occurrence analysis. First, the matrix layout needs to include the species names in rows and the sites in the columns. Second, the following models should be used: 1) Fixed-Fixed: in this model, the row and column sums of the matrix are preserved. Thus, each random community contains the same number of species as the original community (fixed column) and each species occurs with the same frequency as in the original community (fixed row). 2) Fixed-Equiprobable: in this algorithm only the row sums are fixed and the columns are treated as equiprobable. This null model considers all the sites (columns) as equally available for all species, which occur in the same proportions as in the original communities. 3) Fixed-Proportional: this model holds the species occurrence totals the same as in the original community and the probability that a species occurs at a site (column) is proportional to the column total for that sample. A null model analysis was carried out using the software Ecosim version 7.0 (Gotelli \& Entsminger 2004, Tino \& Johens 2007, Tondoh 2006, De los Ríos et al. 2008, De los Ríos 2008). Finally a regression analysis using the software Xlstat 5.0 was performed to determine potential associations of chlorophyll " $\mathrm{a}$ " concentrations with species number, percentage of calanoid copepods, percentage of cladocerans and percentage of cyclopoid copepods.

\section{RESULTS}

The studied sites show low chlorophyll concentrations (Tab. I). The calanoid copepods Boeckella gracilis (Daday, 1902) and $C$. dubia were found at all studied sites (Tab. I). In addition, the following crustaceans were encountered in many of studied sites: D. pulex, Mesocyclops longisetus (Thiebaud, 1912), Chydorus sphaericus (O.F. Müller, 1785), Diaphanosoma chilense (Daday, 1902), and Hyalella araucana (Grosso \& Peralta, 1999) (Tab. I). The overall species number was low, between three species for Negra and Del Risco ponds, and a maximum of six species for Escondida pond (Tab. I). The results of the null model analysis revealed the absence of regulatory factors for all simulations (Tab. II). Many of the studied sites showed a notorious abundance of calanoids copepods and low cladoceran abundance (Tab. III).

The results of the regression analysis did not indicate a significant association between chlorophyll concentration with either species number or with percentage of cyclopoid (Fig. 1). A significant inverse association was observed between chlorophyll concentrations and relative percentages of calanoid, whereas a weak significant direct association was observed between chlorophyll concentrations and percentage of cladocerans (Fig. 1).

Table II. Results of null model analysis for co-occurrence of species at the studied sites ( $\mathrm{p}$ values lower than 0.05 denotes random absence).

\begin{tabular}{lccccc}
\hline & Observed index & Mean index & Standard effect size & Variance & $p$ \\
\hline Fixed-Fixed & 2.523 & 2.581 & 0.409 & 0.019 & 0.683 (n.s) \\
Fixed-Proportional & 2.523 & 2.394 & 0.239 & 0.289 & 0.456 (n.s) \\
Fixed-Equiprobable & 2.523 & 2.205 & 0.548 & 0.336 & 0.334 (n.s) \\
\hline
\end{tabular}

Table III. Percentage of species reported per site.

\begin{tabular}{lrrrrrrrrr}
\hline & Seca & Negrita & De los Patos & Del Risco & Negra & Escondida & Bella & Los Pastos & Vaca Hundida \\
\hline B. gracilis & 1 & 17 & 7 & 75 & 98 & 70 & 96 & 12 & 8 \\
H. araucana & 0 & 0 & 0 & 0 & 1 & 0 & 0 & 0 & 0 \\
C. dubia & 66 & 36 & 0 & 16 & 0 & 5 & 1 & 2 & 2 \\
D. pulex & 1 & 2 & 1 & 0 & 0 & 10 & 1 & 73 & 44 \\
D. chilense & 0 & 0 & 89 & 0 & 0 & 5 & 2 & 1 & 44 \\
Ch. sphaericus & 1 & 0 & 0 & 0 & 0 & 5 & 0 & 0 & 0 \\
M. longisetus & 31 & 45 & 3 & 9 & 1 & 5 & 0 & 12 \\
\hline
\end{tabular}



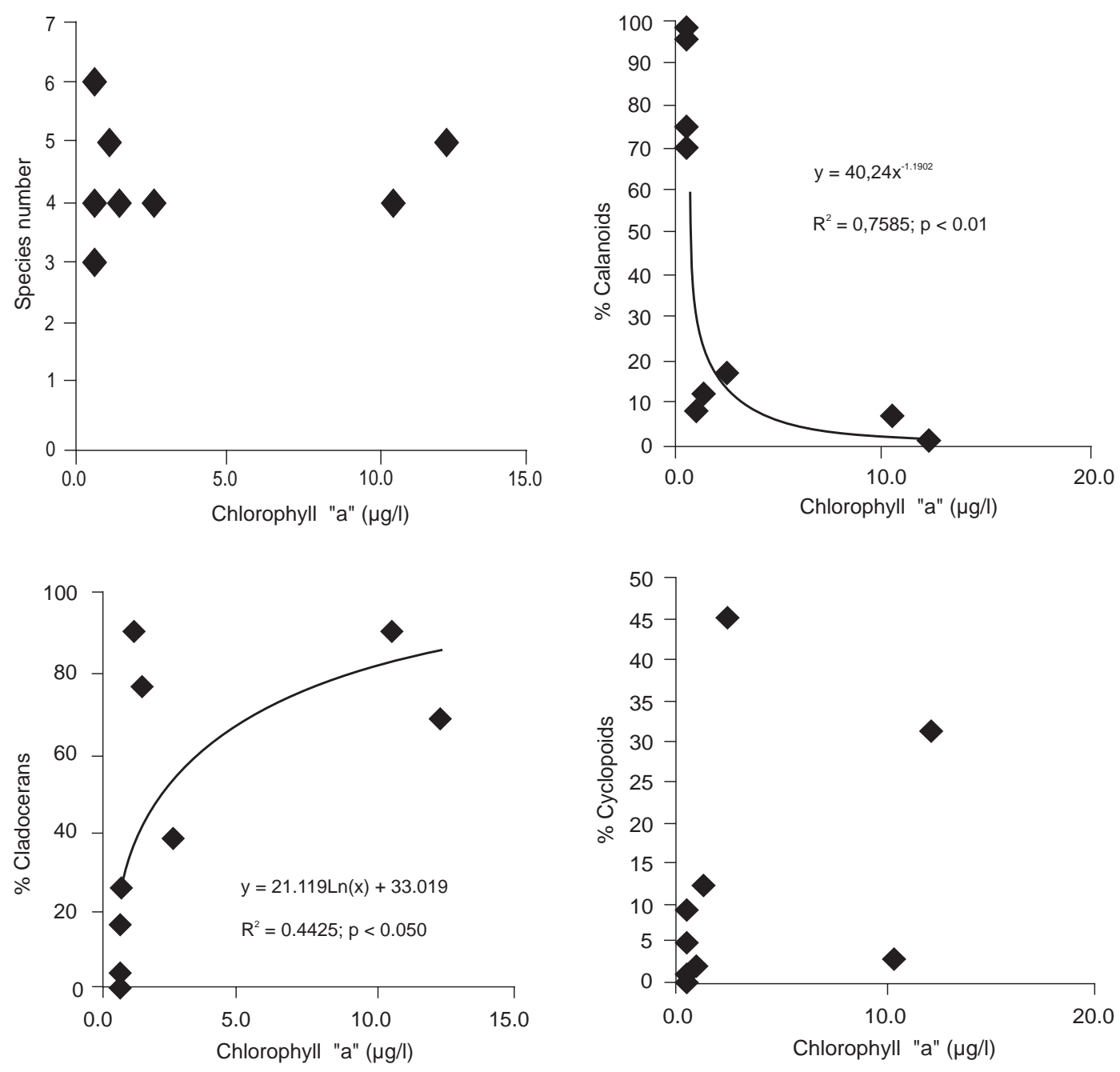

Figure 1. Graph of associations between species number, calanoid, cladoceran and cyclopoid percentage with chlorophyll concentration for studied sites.

\section{DISCUSSION}

The results obtained in the present study revealed a low species richness (Tab. I) and high predominance of calanoids (Tab. III) in many of the studied sites. This pattern is in agreement with other similar studies on oligotrophic lakes in Argentinean Patagonia (Modenutri et al. 1998), New Zealand (Jeppensen et al. 1997, 2000), and Chilean large and deep Patagonian lakes (Soтo \& ZúÑIga 1991, De los Ríos \& Soto 2006, 2007a, Sото \& De los Ríos 2006). The increase in the relative abundance of daphnids (Cladocera) when chlorophyll concentrations are high, observed for a few studied sites (Tab. III and Fig. 1), agrees with previous descriptions for lakes in Chilean Patagonia (Soto \& Zúñiga 1991, Soto \& De los Ríos 2006, De los Ríos \& Soto 2007b, De los Ríos et al. 2007), and New Zealand
(JePpensen et al. 1997, 2000). Nevertheless, the present study did not find associations between species number and chlorophyll concentration (Fig. 1), a situation that differs from descriptions for the Chilean Patagonian lakes, for which a direct association between species number and chlorophyll concentration had been reported (Sото \& ZúñIgA 1991, Sото \& De Los Ríos 2006, De los Ríos \& Soto 2007b, De los Ríos et al. 2007). The results of null model that denoted the absence of regulator factors would be due presence of low species number with many species repeated in practically all studied sites (DE Los Ríos 2008, DE los Ríos et al. 2008), or environmental homogeneity (Tondoh 2006, Tiнo \& Johens 2007).

Some species reported in the present study, such as $B$. gracilis, M. longisetus, D. pulex, D. chilense, C. dubia, Ch. sphaericus and $H$. araucana, were reported previously from Chilean 
Patagonian lakes (GonzÁlez 2003, De los Ríos et al. 2007, De los Ríos \& Soto 2007b, De los Ríos \& Romero-Mieres 2009). The presence of $B$. gracilis in all studied sites is a new report, because, since only rarely it has been reported for Chilean lakes (MENUMARque et al. 2000). Nevertheless, in recent studies, this species was reported from high mountain lakes in northern Patagonia (Trochine et al. 2006, De Los Rios et al. 2007). In general, the species found in our study are the same as those reported for other similar Argentinean and Chilean small lakes in the Andes mountains of northern Patagonia $\left(38-41^{\circ} \mathrm{S}\right)$. Furthermore, the regulatory mechanisms of the local community are similar to those reported for other lakes and ponds of Chilean Patagonia (38-51요.

Our results indicate that unpolluted freshwater bodies have similar regulatory mechanisms as those reported for the Patagonian lakes of Chile and Argentina. These results are important for management, considering the importance of these water bodies as habitats for aquatic birds (AraYA \& Millie 2005), and tourism activities due their unpolluted conditions (STEINHART et al. 1999, 2002).

\section{ACKNOWLEDGEMENTS}

The present study was funded by project DGI-CDA-01, of the Research Direction of the Catholic University of Temuco.

\section{LITERATURE CITED}

Araya, J.M. \& L. Zúñiga. 1985. Manual taxonómico del zooplancton lacustre de Chile. Boletín Informativo Limnológico, Universidad Austral de Chile 8: 1-110.

Araya, B. \& G. Millie. 2005. Guía de campo de las aves de Chile. Santiago de Chile, Editorial Universitaria, 406p.

BAYLY, I.A.E. 1992. Fusion of the genera Boeckella and Pseudoboeckella (Copepoda) and revision of their species from South American and sub-Antarctic Islands. Revista Chilena de Historia Natural (1): 17-63.

DE Los Ríos, P. 2008. A null model for explain crustacean zooplankton assemblages in Central and Southern Patagonian water bodies. Anales del Instituto de la Patagonia 36 (1): 25-33.

De los Ríos, P. \& M. Romero-Mieres. 2009. Littoral crustaceans of lakes of Conguillío National Park (38 ${ }^{\circ}$, Araucania Region, Chile). Crustaceana 82 (1): 117-119.

De Los Ríos, P. \& D. Soто. 2006. Effects of the availability of energetic and protective resources on the abundante of daphnids (Cladocera, Daphnidae) in Chilean Patagonian lakes. Crustaceana 79 (1): 23-30.

De los Ríos, P. \& D. Soto. 2007a. Eutrophication and dominante of daphnids (Crustacea) in a deep subtropical lake (lake Llanquihue, Chile). Polish Journal of Ecology 55 (1): 191193.

De los Ríos, P. \& D. Soto. 2007b. Crustacean (Copepoda and Cladocera) zooplancton richness in Chilean Patagonian lakes. Crustaceana 80 (3): 285-296.

De los Ríos, P.; N. Rivera \& M. Galindo. 2008. The use of null models for explain crustacean zooplankton associations in shallow water bodies of the Magellan region, Chile. Crustaceana 81 (10): 1219-1228.

De los Ríos, P.; E. Hauenstein; P. Acavedo \& X. Jague. 2007. Littoral crustaceans in mountain lakes of Huerquehue National Park $\left(38^{\circ} \mathrm{S}\right.$, Araucania region, Chile). Crustaceana 80 (4): 401410 .

GonZÁLEZ, E.R. 2003. The freshwater amphipod Hyalella Smith, 1974 in Chile (Crustacea, Amphipoda). Revista Chilena de Historia Natural 76 (4):623-637.

Gotelli, N.J. 2000. Null model of species co-occurrence patterns. Ecology 81 (9): 2606-2621.

Gotelli, N.J. 2001. Research frontiers in null model analysis. Global Ecology and Biography 10 (4): 337-343.

Gotelli, N.J., \& G.L. EnTSMinger. 2004. Ecosim: null models software for ecology. Version 7. Acquired Intelligence Inc. and Kesey-Bear. Jericó, VT 05465. Available online at: http:/ /garyentsminger.com/ecosim.htm [Accessed: 20/XII/2008].

Hoffman, A. 2005. Flora silvestre de Chile, zona Araucana. Ediciones Fundación Claudio Gay, Santiago de Chile. 258 p.Luebert, F. \& P. Pliscoff. 2006. Sinopsis bioclimática y vegetacional de Chile. Santiago de Chile, Editorial Universitaria, 316p.

Jeppensen, E.; T.L. Lauridsen; S.F. Mitchell \& C.W. Burns. 1997. Do planktivorous fish structure the zooplankton communities in New Zealand lakes? New Zealand Journal of Marine and Freshwater Research 31 (2): 163-173.

Jeppensen, E.; T.L. Lauridsen; S.F. Mitchell; K. Christoffersen \& C.W. BurNs. 2000. Trophic structure in the pelagial of 25 shallow New Zealand lakes: changes along nutrient and fish gradients. Journal of Plankton Research 22 (5): 951-968.

Menu-Marque, S.; J.J. Morrone \& C. Locascio de Mitrovich. 2000. Distributional pattern of the South American species of Boeckella (Copepoda, Centropagidae): a track analysis. Journal of Crustacean Biology 20 (2): 262-272.

ModenutTi, B.E.; E.G. Balseiro; C.P. Queimaliños; D.A. AÑon-SuareZ; M. Diéguez \& R.J. Albariño. 1998. Structure and dynamics in South American temperate lakes and reservoirs. Lakes and Reservoirs Research and Management 3 (3/4): 179-186.

Pilati, A. \& S. Menu-Marque. 2002. Morphological comparison of Mesocyclops araucanus (Campos et al., 1974) and M. longisetus (Thiebaud, 1912) and first descriptions of their males. Beaufortia 52 (1): 45-52.

ReID, J. 1985. Chave de identificação e lista de referências bibliográficas para as espécies continentais sulamericanas de vida livre da ordem Cyclopoida (Crustacea, Copepoda). Boletim Zoológico da Universidade de São Paulo 9 (1): 17-143.

Soto, D. \& P. De los Ríos. 2006. Influence of trophic status and conductivity on zooplancton composition in lakes and ponds of Torres del Paine National Park (Chile). Biologia Bratislava 61 (5): 541-546. 
Soto, D. \& L. ZúÑIGA. 1991. Zooplankton assemblages of Chilean temperate lakes: a comparison with North American counterparts. Revista Chilena de Historia Natural 64 (4): 569-581.

Steinhart, G.S.; G. Likens \& D. Soto. 1999. Nutrient limitation in lago Chaiquenes (Parque Nacional Alerce Andino, Chile): evidence from nutrient enrichment experiments and physiological assays. Revista Chilena de Historia Natural 72 (4): 559-568.

Steinhart, G.S.; G. Likens \& D. Soto. 2002. Physiological indicators of nutrient deficiency in phytoplankton in southern Chilean lakes. Hydrobiologia 489 (1/3): 21-27.
Tino, S. \& J Johens. 2007. Co-occurrence of earthworms in urban surroundings: a null models of community structure. European Journal of Soil Biology 43 (2): 84-90.

TonDOH, J.E. 2006. Seasonal changes in earthworm diversity and community structure in central Cote d'Ivorie. European Journal of Soil Biology 42 Supplement (1): 334-340.

Trochine, C.; B. Modenutti \& E.G. Balseiro. 2006 Influence of spatial heterogeneity on predation by the flatworm Mesostoma ehrenbergii (Focke) on calanoid and cyclopoid copepods. Journal of Plankton Research 28 (3): 267-274.

WetzeL, R. \& G. Likens. 1991. Limnological analysis. New York, Springer Verlag, 391p.

Submitted: 05.I.2009; Accepted: 18.I.2010.

Editorial responsibility: Neusa Hamada 